\title{
The Effect of Glucagon Infusion on Kidney Function in Short-term Insulin-dependent Juvenile Diabetics
}

\author{
H.-H. Parving, J. Sandahl Christiansen, I. Noer, B. Tronier, and C. E. Mogensen \\ Department of Clinical Physiology and Department of Medicine C, Bispebjerg Hospital, Department of Medicine F, \\ Herlev Hospital, Steno Memorial Hospital, Novo Research Laboratories, Copenhagen, \\ and Second University Clinic of Internal Medicine, Kommunehospitalet, Århus, Denmark
}

Summary. Kidney function was studied in nine, metabolically well controlled, short-term insulindependent male diabetics before and during glucagon infusion of 4 to 5 and 8 to $10 \mathrm{ng} / \mathrm{kg} / \mathrm{min}$. Glomerular filtration rate, effective renal plasma flow (steadystate infusion technique, with urinary collections, using ${ }^{125} \mathrm{I}$-iothalamate and ${ }^{131} \mathrm{I}$-iodohippurate), and urinary albumin and $\beta_{2}$-microglobulin excretion rates were measured. The mean plasma glucagon concentration increased during infusion from $254 \pm 19 \mathrm{pg} /$ $\mathrm{ml}$ to $440 \pm 31 \mathrm{pg} / \mathrm{ml}$ (low dose) and $730 \pm 52 \mathrm{pg} / \mathrm{ml}$ (high dose). Glomerular filtration rate increased in all subjects from $133 \pm 5$ before the glucagon infusion to $141 \pm 4$ with the low dose, and $148 \pm 7 \mathrm{ml} /$ $\min / 1.73 \mathrm{~m}^{2}$ with the high dose $(\mathrm{p}<0.01)$. The increase in glomerular filtration rate correlated with the rise in plasma glucagon concentration $(\mathrm{r}=0.67$; $\mathrm{p}<0.01$ ). Renal plasma flow increased from 530 \pm 21 before the glucagon infusion to $555 \pm 20$ with the low dose and $572 \pm 29 \mathrm{ml} / \mathrm{min} / 1.73 \mathrm{~m}^{2}$ with the high dose $(\mathrm{p}<0.01)$. Urinary $\beta_{2}$-microglobulin excretion rate rose from $5.8 \pm 1.0$ before infusion to $8.7 \pm 1.7$ with the low dose, and $17.9 \pm 5.7 \mu \mathrm{g} \times$ $10^{-2} / \mathrm{min}$ with the high dose $(\mathrm{p}<0.01)$. Urinary albumin excretion remained unchanged during the glucagon infusion. These results suggest that glucagon may contribute to the reversible elevation of glomerular filtration rate typically found in poorly regulated insulin-dependent diabetics, but not to the moderate elevation found in well controlled diabetics.

Key words: Albumin, $\beta_{2}$-microglobulin, glomerular filtration rate, glucagon, insulin-dependent diabetes, kidney function, renal plasma flow.

Pronounced alterations in kidney function are present in poorly controlled short-term insulin-dependent diabetics. These include increased glomerular filtration rate (GFR), increased filtration fraction (FF), increased urinary albumin and $\beta_{2}$-microglobulin excretion rates, and normal or slightly elevated renal plasma flow (RPF) $[4,13,15]$. The elevations in GFR and FF are less, and the urinary albumin and $\beta$-microglobulin excretion rates are normal in clinically well controlled short-term insulin-dependent diabetics [13, 15]. Hyperglycaemia [2], hypoxia [5], and growth hormone [13] have all been suggested as causes of the GFR elevation, but we could find no evidence for the involvement of these proposed mediators [15].

Glucagon infusion in pharmacological doses causes enhanced GFR in animals and man $[3,6,11]$, and recently we have shown that moderate glucagon infusions increase GFR in normal man [16]. Since the infusion induced moderately elevated plasma glucagon levels, as typically found in diabetics in ketoacidosis, we suggested that hyperglucagonaemia might contribute to the reversible alterations of kidney function in poorly controlled insulin-dependent diabetics.

To test this hypothesis, we have determined GFR, RPF, urinary albumin and $\beta_{2}$-microglobulin excretion rates before and during glucagon infusion in metabolically well controlled, short-term juvenile diabetics.

\section{Material and Methods}

Nine male juvenile diabetics, aged 18 to 33 years (mean 27 years), all of whom had been fully informed of the nature of the study before giving their consent, were investigated. All patients were "ketosis-prone". Duration of diabetes ranged from 1 years to 10 years (mean 3 years). Clinical signs of diabetic retinopathy, nephropathy and neuropathy were absent in all patients. None of the patients were taking any drugs other than insulin. Mean percent ideal body weight was 97 (range 87 to $103 \%$ ). Ketonuria was not present. Average daily urinary glucose excretion during the last three days before the investigation was $23 \mathrm{~g}$ (range $0-77 \mathrm{~g}$ ). Mean daily insulin dose was 41 Units (range 12 to 80 ). None of the subjects received insulin on the day of investigation. 
Table 1. Kidney function during glucagon infusion in 9 insulin-dependent diabetics

\begin{tabular}{|c|c|c|c|c|c|c|c|c|c|c|c|c|}
\hline \multirow[t]{2}{*}{$\begin{array}{l}\text { Subject } \\
\text { no. }\end{array}$} & \multicolumn{3}{|c|}{$\begin{array}{l}\text { Plasma glucagon } \\
(\mathrm{pg} / \mathrm{ml})\end{array}$} & \multicolumn{3}{|c|}{$\begin{array}{l}\text { GFR } \\
\left(\mathrm{ml} / \mathrm{min} / 1.73 \mathrm{~m}^{2}\right)\end{array}$} & \multicolumn{3}{|c|}{$\begin{array}{l}\mathrm{RPF} \\
\left(\mathrm{ml} / \mathrm{min} / 1.73 \mathrm{~m}^{2}\right)\end{array}$} & \multicolumn{3}{|c|}{$\begin{array}{l}\text { Plasma glucose } \\
(\mathrm{mmol} / 1)\end{array}$} \\
\hline & I & II & III & I & II & III & I & II & III & I & II & III \\
\hline 1 & 260 & 410 & 870 & 116 & 122 & 128 & 513 & 533 & 533 & 6.4 & 6.3 & 7.1 \\
\hline 2 & 210 & 290 & 510 & 140 & 149 & 152 & 628 & 624 & 623 & 4.1 & 4.6 & 5.4 \\
\hline 3 & 180 & 360 & 670 & 146 & 153 & 159 & 575 & 586 & 597 & 6.7 & 7.9 & 8.1 \\
\hline 4 & 230 & 390 & & 134 & 141 & & 470 & 497 & & 8.7 & 9.1 & \\
\hline 5 & 260 & 520 & 790 & 123 & 136 & 160 & 482 & 504 & 622 & 6.4 & 8.2 & 7.6 \\
\hline 6 & 300 & 520 & 810 & 140 & 147 & 161 & 553 & 582 & 614 & 11.5 & 13.4 & 14.4 \\
\hline 7 & 370 & 570 & & 132 & 139 & & 570 & 617 & & 13.0 & 17.5 & \\
\hline 8 & 210 & 400 & & 154 & 159 & & 551 & 597 & & 13.4 & 15.9 & \\
\hline 9 & 270 & 500 & 730 & 113 & 120 & 126 & 424 & 458 & 445 & 8.8 & 10.3 & 11.3 \\
\hline $\mathrm{p}$ & \multicolumn{3}{|c|}{$<0.01<0.05$} & \multicolumn{3}{|c|}{$<0.01<0.05$} & \multicolumn{2}{|c|}{$<0.01$} & $S$ & \multicolumn{2}{|c|}{$<0.01$} & IS \\
\hline
\end{tabular}

$I=$ Mean control values ( 4 periods)

$\mathrm{II}=$ Mean values during low dose glucagon infusion $(4-5 \mathrm{ng} / \mathrm{kg} / \mathrm{min}$ ) (last 3 periods)

$\mathrm{III}=$ Mean values during high dose glucagon infusion $(8-10 \mathrm{ng} / \mathrm{kg} / \mathrm{min})$ (last 3 periods)

$\mathrm{p}$ values show comparisons between I and II, and II and III respectively. Wilcoxon's test

Investigations were started at $0900 \mathrm{~h}$ in the fasting state. Subjects were supine during the investigation, standing up only during urinary voiding. To promote diuresis $250 \mathrm{ml}$ of water was given every $20 \mathrm{~min}$, starting one $\mathrm{h}$ before the experiment and continuing throughout the clearance procedure. All the variables mentioned below were measured in each 20 -min clearance period.

GFR and RPF were measured using a steady-state infusion technique with ${ }^{125} \mathrm{I}$-iothalamate and ${ }^{131} \mathrm{I}$-iodohippurate, respectively [13]. Urinary albumin and $\beta_{2}$-microglobulin were measured by radioimmunoassays $[7,12]$. Plasma glucagon concentration was measured, after extraction, by radioimmunoassay, using antiserum K964 [9]. Plasma glucose was measured by a glucose oxidase method on an Autoanalyser. Total plasma protein concentration was measured by refractometry. Blood pressure and pulse rate were determined during each clearance period.

The mean intra-individual coefficient of variation in the four consecutive control clearance periods was as follows: $3.3 \%$ (GFR), 3.7\% (RPF), 30.2\% (albumin excretion), $22.4 \%\left(\beta_{2}\right.$-microglobulin excretion).

\section{Protocol}

After $40 \mathrm{~min}$ of constant infusion, 4 control clearance periods of $20 \mathrm{~min}$ each were performed. Glucagon (Novo, Copenhagen) infusion $(4-5 \mathrm{ng} / \mathrm{kg} / \mathrm{min})$ was then started and continued for 4 further 20 min clearance periods, followed immediately by another 3 twenty min clearance periods with glucagon given at 8 to $10 \mathrm{ng} / \mathrm{kg} /$ min.

The effect of high dose glucagon infusion could not be evaluated in 3 patients: one was unable to pass urine and two patients developed nausea and vomiting during the high dose infusion.

The results were compared with those obtained during glucagon infusion $(10 \mathrm{ng} / \mathrm{kg} / \mathrm{min})$ in six normal male subjects (mean age 25 years) by exactly the same technique [16]. Wilcoxon's nonparametric test for paired comparison was used for statistical analysis, excluding the values for the transitional clearance periods (5 and 9), the first periods after hormone infusion was initiated and when it was later increased. Wilcoxon's test for unpaired comparison was used to test differences between diabetic and control subjects.

\section{Results}

Table 1 shows the individual changes in plasma glucagon and kidney function induced by glucagon infusion in 9 short-term insulin-dependent diabetics. Plasma glucagon concentration increased rapidly, reaching a steady level of about $440 \pm 21 \mathrm{pg} / \mathrm{ml}$ within $30 \mathrm{~min}$ after the start of the low dose infusion. A new plateau level of about $730 \pm 52 \mathrm{pg} / \mathrm{ml}$ was obtained $30 \mathrm{~min}$ after infusion with the high glucagon dose. The average control glucagon concentration was $254 \pm 19 \mathrm{pg} / \mathrm{ml}$. GFR increased in all subjects after the start of the low dose infusion and remained elevated during the infusion. The mean value in the last 3 clearance periods was $141 \pm 4 \mathrm{ml} / \mathrm{min} / 1.73 \mathrm{~m}^{2}$ compared to a control value of $133 \pm 5 \mathrm{ml} / \mathrm{min} /$ $1.73 \mathrm{~m}^{2}(\mathrm{p}<0.01)$. A further increase took place during the high dose infusion, with a mean GFR in the last 3 periods of $148 \pm 7 \mathrm{ml} / \mathrm{min} / 1.73 \mathrm{~m}^{2}(\mathrm{p}<$ $0.01)$. RPF increased in all patients, save one: average values, $530 \pm 21 \mathrm{ml} / \mathrm{min} / 1.73 \mathrm{~m}^{2}$ (before), $555 \pm 20 \mathrm{ml} / \mathrm{min} / 1.73 \mathrm{~m}^{2}$ (low dose), and $572 \pm 29$ $\mathrm{ml} / \mathrm{min} / 1.73 \mathrm{~m}^{2}$ (high dose), $(\mathrm{p}<0.01$ ). Filtration fraction remained unchanged during the infusion with mean values of $0.25 \pm 0.01,0.26 \pm 0.01$, and $0.26 \pm 0.01$ respectively.

RPF and GFR before and during the glucagon infusion showed a close correlation; $(\mathrm{r}=0.58 ; \mathrm{p}<$ 0.01 ) (Fig. 1).

Figure 2 shows the individual changes in GFR in relation to the changes in plasma glucagon concentration. A significant positive correlation was found between the two variables $(r=0.67 ; p<0.01)$. No 
significant correlation was found between plasma glucagon concentration and RPF.

Urinary albumin excretion rate remained unchanged during the glucagon infusion; $5.5 \pm 1.0$ (before), $5.6 \pm 1.2$ (low dose), and $5.9 \pm 1.7 \mu \mathrm{g} / \mathrm{min}$ (high dose). Urinary $\beta_{2}$-microglobulin excretion rose during the infusion to mean of $8.7 \pm 1.7 \mu \mathrm{g} \times 10^{-2} /$ min during hig dose infusion, low dose glucagon, and $17.9 \pm 5.7 \mu \mathrm{g} \times 10^{-2} / \mathrm{min}$ during high dose infusion as fram a mean control value of $5.8 \pm 1.0 \mu \mathrm{g} \times 10^{-2} / \mathrm{min}$ $(\mathrm{p}<0.01)$. An increase in urine volume also occurred during the infusion: $11.5 \pm 0.9 \mathrm{ml} / \mathrm{min}$ (before), $15.3 \pm 0.8 \mathrm{ml} / \mathrm{min}$ (low dose), and $17.4 \pm 1.1 \mathrm{ml} / \mathrm{min}$ (high dose), $(\mathrm{p}<0.01)$.

Blood pressure and pulse rate were the same before and during the low and high dose glucagon infusion. There was a slight decrease in plasma protein levels during the investigations: $65 \mathrm{~g} / \mathrm{l}$ (before), $64 \mathrm{~g} / 1$ (low dose) and $63 \mathrm{~g} / \mathrm{l}$ (high dose), $(\mathrm{p}<0.05$ ).

The basal GFR was significantly elevated in the diabetics $\left(133 \pm 5 \mathrm{ml} / \mathrm{min} / 1.73 \mathrm{~m}^{2}\right)$ compared to our normal value of $115 \pm 3 \mathrm{ml} / \mathrm{min} / 1.73 \mathrm{~m}^{2}[16],(\mathrm{p}<$ $0.01)$. Despite this, the increase in GFR for a given increase in plasma glucagon concentration was nearly 2 times greater in the diabetics compared to normals (Fig. 2), ( $p<0.05)$. RPF was about the same in the diabetics, mean $530 \pm 21 \mathrm{ml} / \mathrm{min} / 1.73 \mathrm{~m}^{2}$, and in the normals $552 \pm 28 \mathrm{ml} / \mathrm{min} / 1.73 \mathrm{~m}^{2}$. RPF remained unchanged during the glucagon infusion in normals [16], while a significant in crease in RPF occurred in the diabetics (Table 1). The basal plasma glucagon concentration was slightly elevated in the diabetics, mean $254 \pm 19 \mathrm{pg} / \mathrm{ml}$, compared to the normal value of $200 \pm 16 \mathrm{pg} / \mathrm{ml}$.

\section{Discussion}

The major novel observation in the present study is that a low rate of infusion of glucagon, resulting in slightly elevated plasma glucagon levels, induced a rise in GFR in well controlled diabetics (mean rise, $8 \mathrm{ml} / \mathrm{min} / 1.73 \mathrm{~m}^{2}$ ). The plasma glucagon elevation achieved is comparable with that found in poorly controlled insulin-dependent diabetics without ketoacidosis [8]. It is conceivable therefore that glucagon contributes to the reversible GFR elevation typically found in poorly controlled insulin-dependent diabetics. Glucagon apparently does not contribute to the elevated GFR found in most well controlled insulin-dependent diabetics where, as in the present study, the basal plasma glucagon concentration was only slightly elevated compared to control [16].

The demonstrated increase in glomerular filtration surface area in newly diagnosed insulin-dependent $(+80$ percent $)$ and short-term insulin-dependent

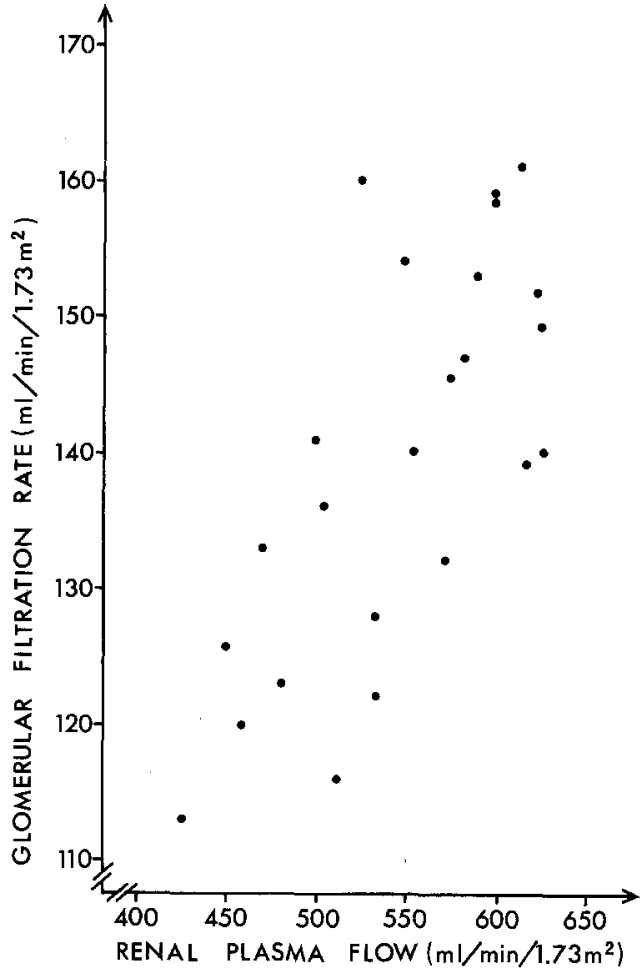

Fig. 1. Renal plasma flow and glomerular filtration rate before and during intravenous glucagon infusion in nine short-duration insulin-dependent diabetics. $\mathrm{r}=0.58(\mathrm{p}<0.01)$

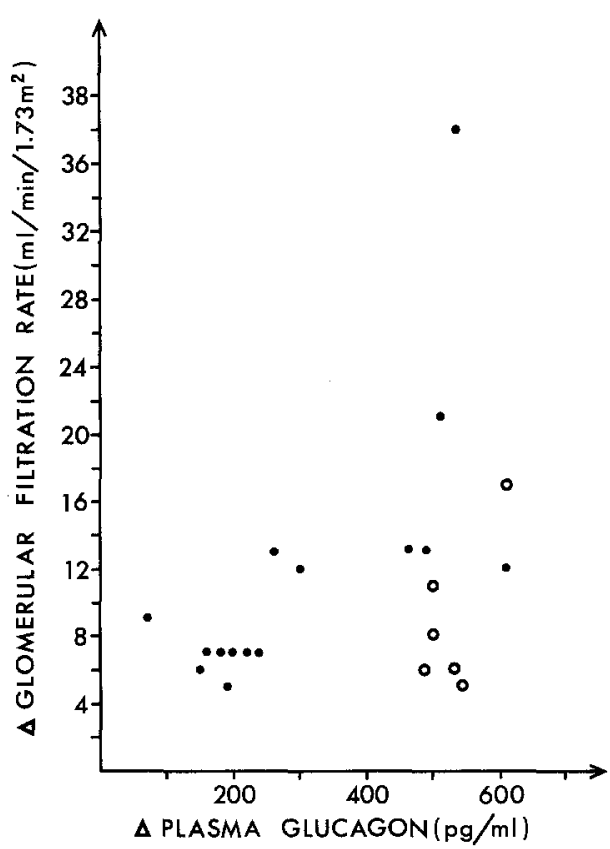

Fig. 2. Correlation between the rise in plasma glucagon concentration and the increase in glomerular filtration rate in nine shortduration insulin-dependent diabetics $(\bullet) .(\mathrm{r}=0.67 ; \mathrm{p}<0.01)$. Note that the increase in glomerular filtration rate for a given increase in plasma glucagon concentration is nearly 2 times greater in the diabetics compared to normals $(0),(\mathrm{p}<0.05)$. There was no significant correlation between $\triangle$ GFR and $\triangle$ plasma glucagon in normal subjects 
diabetics ( +40 percent) has been suggested as the dominant mechanism for the GFR elevation found before and during insulin treatment $[10,19]$. However, the rapid reversibility of GFR induced by changing metabolic control, suggests functional alterations to be quantitatively important for the GFR elevation. Mogensen [13] clearly demonstrated that GFR in newly diagnosed untreated insulin-dependent juvenile diabetics could be reduced considerably during the first 2 weeks of insulin treatment, e.g., 158 (before) and 137 (during insulin therapy) $\mathrm{ml} / \mathrm{min} /$ $1.73 \mathrm{~m}^{2}$. Parving et al. [17] measured GFR in 7 shortterm insulin-dependent juvenile diabetics during good and poor metabolic regulation (mean glucose 6.4 and $14.3 \mathrm{mmol} / 1$, respectively). The interval between the two investigations was less than 10 days. GFR was elevated in all patients during poor metabolic control, mean $121 \mathrm{ml} / \mathrm{min} / 1.73 \mathrm{~m}^{2}$, but only $101 \mathrm{ml} / \mathrm{min} / 1.73 \mathrm{~m}^{2}$ during good control. Thus short-term changes in metabolic control induce marked alterations in GFR. The metabolically induced alteration in GFR can hardly be explained by the demonstrated increase in glomerular filtration surface area, since this abnormality is only slowly reversible and essentially unchanged after 5 weeks of insulin treatment in newly diagnosed juvenile diabetics [10]. The enlargement of the glomerular filtration surface area might of course be important for the more moderate and slowly reversible GFR elevation found in clinically well controlled insulin-dependent juvenile diabetics.

Recently Brenner and Humes [1] reviewed the variables regulating GFR. These include RPF, hydraulic and oncotic pressures and the glomerular permeability-surface area-product. The finding of an unchanged urinary albumin excretion rate in spite of a slightly reduced tubular protein reabsorption does not suggest an increased permeability-surface areaproduct to be present during glucagon infusion. The effect on GFR of the slight decrease in total plasma protein (oncotic pressure) is negligible [1]. The elevated GFR can hardly be explained by increased intraglomerular filtration pressure, since the filtration fraction remained unchanged during the glucagon infusion. The present finding of an elevated RPF and a relationship between RPF and GFR, suggest $\mathrm{RPF}$ as the main mechanism of the observed GFR elevation. Increased RPF and GFR has been demonstrated in man and dog, using much larger amounts of glucagon than in the present study $[3,6,11]$. Finally it should be mentioned that RPF is quantitatively the dominant factor in the regulation of GFR [1]. Since arterial blood pressure remained unchanged in the present and previous studies, this suggests that glucagon induces a dilatation of the glomerular arterioles [18].
The finding of an increased $\beta_{2}$-microglobulin excretion confirms our previous observation in normal subjects that glucagon reduces the tubular reabsorption of protein [16]. Insulin intravenously has exactly the opposite effect on the tubular handling of protein [14].

It is not likely that the small rise in plasma glucose contributed to the above mentioned kidney function alterations, as discussed previously [13].

It should be mentioned in conclusion that glucagon induces a more pronounced increase in GFR and RPF in the diabetic than in the normal subjects [16]. This difference may be due to the glucagon induced enhancement of insulin secretion in normal subjects leading to a reduced glucagon/insulin ratio. This suggestion is supported by the finding that 7 to 8 IU of insulin given intravenously in short-term juvenile diabetics have the opposite effect to those noted during glucagon infusion, i.e., reduced GFR and RPF [14].

Acknowledgements. This study was supported by grants from Landsforeningen for Sukkersyge, King Christian X's Foundation and The Danish Heart Foundation.

\section{References}

1. Brenner BM, Humes HO (1977) Mechanics of glomerular ultrafiltration. N Engl J Med 297: 148-154

2. Brøchner-Mortensen J (1973) Glomerular filtration rate and extracellular fluid volumes during normoglycemia and moderate hyperglycemia in diabetes. Scand J Clin Lab Invest 32: 311-316

3. Butturini U Von, Bonomini V (1958) Über die Wirkung von Glucagon und Insulin auf Nierenfunktion, Harnausscheidung der Phosphat-, Bicarbonat- und Ammoniakionen und titrierbare Acidität beim Mensch. Helv Med Acta 5: 617-624

4. Christiansen JS, Parving H-H, Gammelgaard J, Holm $\mathrm{HH}$, Svendsen PAa (1979) Kidney function and kidney size in newly diagnosed insulin-dependent diabetics before and during initial insulin therapy. Excerpta Med 481: 202

5. Ditzel J, Junker K (1972) Abnormal glomerular filtration rate, renal plasma flow, and renal protein excretion in recent and short-term diabetics. Br Med J II: 13-19

6. Elrick H, Huffman ER, Hlad CJ, Whipple N, Staub A, Smith AE, Yearwood-Drayton V (1958) Effects of glucagon on renal function in man. J Clin Endocrinol Metab 18: 813-824

7. Evrin P-E, Peterson PA, Wide L, Berggaard J (1971) Radioimmunoassay of $\beta_{2}$-microglobulin in human biological fluids. Scand J Clin Lab Invest 28: 439-444

8. Gerich JE, Tsalikian E, Lorenzi M, Schneider V, Bohanon NV, Gustavson G, Karam JH (1975) Normalization of fasting hyperglucagonemia and excessive glucagon responses to intravenous arginine in human diabetes mellitus by prolonged infusion of insulin. J Clin Endocrinol Metab 41: $1178-1180$

9. Heding LG (1971) Radioimmunological determination of pancreatic and gut glucagon in plasma. Diabetologia 7: 10-19

10. Kroustrup JP, Gundersen HJG, Østerby R (1977) Glomerular size and structure in diabetes mellitus. III. Early enlargement of the capillary surface. Diabetologia 13: 207-210 
11. Levy M (1975) The effect of glucagon on glomerular filtration rate in dogs during reduction of renal blood flow. Can J Physiol Pharmacol 53: 660-668

12. Miles DW, Mogensen CE, Gundersen HJG (1970) Radioimmunoassay for urinary albumin using a single antibody. Scand J Clin Lab Invest 26: 5-11

13. Mogensen CE (1972) Kidney function and glomerular permeability to macromolecules in juvenile diabetes. Dan Med Bull 19 (Suppl 3): 1-40

14. Mogensen CE, Christensen NJ, Gundersen HJG (1978) The acute effect of insulin on renal haemodynamics and protein excretion in diabetics. Diabetologia 15: $1-5$

15. Parving $\mathrm{H}-\mathrm{H}$, Noer $\mathrm{I}$, Deckert T, Evrin P-E, Nielsen SL, Lyngsøe J, Mogensen CE, Rørth M, Svendsen PAa, Trap-Jensen J, Lassen NA (1976) The effect of metabolic regulation on microvascular permeability to small and large molecules in short-term juvenile diabetics. Diabetologia 12: 161-166

16. Parving $\mathrm{H}-\mathrm{H}$, Noer I, Kehlet $\mathrm{H}$, Mogensen $\mathrm{CE}$, Svendsen PAa, Heding LG (1977) The effect of short-term glucagon infusion on kidney function in normal man. Diabetologia 13: $323-325$
17. Parving H-H, Rutili F, Granath $\mathrm{K}$, Noer I, Deckert T, Lyngsøe J, Lassen NA (1979) Effect of metabolic regulation on renal leakiness to dextran molecules in short-term insulindependent diabetics. Diabetologia 17: 157-160

18. Peart WS (1977) The kidney as an endocrine organ. Lancet II: 543-548

19. Østerby R, Gundersen HJG (1975) Glomerular size and structure in diabetes mellitus. I. Early abnormalities. Diabetologia 11: 225-229

Received: May 9, 1979,

and in revised form: June 3, 1980

\section{H.-H. Parving, M. D.}

Department of Clinical Physiology

Bispebjerg Hospital

Bispebjerg Bakke 23

DK-2400 Copenhagen NV

Denmark 